\title{
Indication of Radicalism: Students' Perceptions on Pancasila in the Digital Era
}

\author{
$1^{\text {st }}$ Joan Hesti Gita Purwasih \\ Faculty of Social Science \\ Universitas Negeri Malang \\ Malang, Indonesia \\ joan.hesti.fis@um.ac.id
}

\author{
$2^{\text {nd }}$ Ahmad Arif Widianto \\ Faculty of Social Science \\ Universitas Negeri Malang \\ Malang, Indonesia \\ ahmad.arif.fis@um.ac.id
}

\begin{abstract}
The very rapid development of technology encourages the opening of information flow and communication through internet media. Social media in this case plays an important role in the effectiveness of communication and the spread of information based on internet of things (IoT). The opening of information flow facilitates the dissemination of ideologies across countries so that they can influence citizens' perceptions of certain ideologies. Students as millennial generation who are active in advancing ICT are vulnerable to being influenced by ideologies coming from other countries through literature, videos and web content and social media. This article aimed to describe the high school students' perception on Pancasila in Malang City in this digital revolution era. This research employed an explanatory sequential mixed method and likert scale. A quantitative research was conducted through surveying 300 students as preliminary data. Furthermore, data exploration was carried out qualitatively through in-depth interviews with purposive sampling technique. The result of research results indicated a threat against the future of Pancasila as the state ideology. Some students believe that Pancasila can be replaced with a new, more modern ideology. Even some students state that the Pancasila must be replaced with the Caliphate system. This condition is a logical consequence of the thought pattern of a more open-minded young generation amid disrupted era. Students get a variety of ideological information that wants to change the Pancasila through social media and their social groups.
\end{abstract}

Keywords: ICT, social media, Pancasila, student's perception

\section{INTRODUCTION}

Indonesia is an archipelago state with the fourth largest population number in the world. In addition, Indonesia also has the fifth-ranked internet users (netizen) in the world [1]. The result of Indonesian Internet Service Provider Association (Asosiasi Penyelenggara Jasa Internet Indonesia or APJII)'s survey in 2018 shows that 171.71 millions out of 264.26 millions Indonesian populations are internet users. In addition, considering the result of APJII's survey on 1,116 respondents, there are five quite high hoax issues in
Indonesia: politics (91.8\%), SARA (88.6\%), health (41.2\%), food and beverage $(32.6 \%)$, and financial fraud $(24.5 \%)$. The result of another APJII's survey also shows that Indonesian young generation aged 15-19 years is the largest internet user [2]. In Indonesia such age range is generally composed of Junior High School (about 12-15 years) and Senior High School students (16-19). Considering such age division, it can be seen that SMA students belong to internet user group deserving to take into account. This condition also indicates that the Indonesian Senior High School students are risky of being exposed to hoax through internet media.

One of vulnerable social issue risks in Indonesia is radicalism issue. In relation to the data aforementioned, radicalism phenomenon among students is likely related to their internet using behavior. Previously, radicalism phenomenon among students is due to some causes. The result of survey released by Islam and Reconciliation Study Institution (LaKip) in 2011 shows that almost 50\% of students agree using violence or anarchism to deal with religious and morality problems. About 63\% of 1000 students at Junior and Senior High School level agree sealing other religion's worship places [3]. Such radical religious perception not only harms the well-established social order but also attenuates Pancasila as the state's ideology. The result of LaKip's survey above shows such predisposition, as indicated with $84.8 \%$ students assuming that Pancasila is no longer relevant. More severely, about $76.2 \%$ of teachers also agree that Pancasila should be replaced with the implementation of Islam sharia.

In youth study's perspective, students are the subject vulnerable to radicalism as it is still on transition and identity seeking stages. Azca said that the psychology of youth development is still labile or unstable; therefore it the youths have no had mature personality yet and understanding on outside world [4]. As a result, information flow and knowledge are accepted just the way it is without mature thinking. The characteristic of youth age is divided into two 
classes: teenagers (13-19 years) and young adult (20-24 years).

School is an education institution likely insecure from radicalism effect. Otherwise, the school instead becomes the land of seedling and disseminating religious radicalism. It is because of (1) students' limited religious knowledge so that being vulnerably infiltrated by radicalism, (2) Islam study units at school submitted to the third party so that being vulnerably infiltrated with radicalism, and (3) references and textbooks containing radical statements that can influence the students [5].

The author describes this radical thinking as an iceberg phenomenon. On the surface, it can be seen that this issue is not a threat to be alert to. However, investigated more indepth, this risk really occurs. It is this that the author attempts to prove through a research conducted in Malang and Batu, East Java. The research on radicalism phenomenon among students in these two cities has not been raised specifically by other researchers. Therefore, it becomes the author's foundation to describe that the radicalism iceberg phenomenon lives actually among within society.

\section{METHOD}

This research employed mixed method. Two main research methods were employed: survey and interview. Survey was conducted on 300 student respondents in Malang and Batu city selected using proportional sampling technique. Meanwhile interview was conducted using purposive sampling technique. During questionnaire distribution, the author also conducted discussion with the students having experience with radicalism at school. This attempt equipped the author to find informants to conduct in-depth interview. The result of survey was used to describe the surface condition of radicalism phenomenon. Meanwhile, the author conducted interview to describe the phenomenon beneath the iceberg surface. These techniques were used all at once as validation technique through data collection technique triangulation. The data obtained from these two techniques were analyzed with mutually reinforcing pattern.

\section{RESULT}

The result of research is elaborated in two categories: quantitative and qualitative data. Quantitative data was obtained through survey and qualitative data through interviewing the students.

\section{A. Survey on Students' Perception on Pancasila}

Pancasila is the state ideology of Indonesian people. In addition, According to Law No.10 of 2004 (Article 2), Pancasila is the source of any state's legal sources [6]. This reality is understood adequately by students, as indicated with the students' perception on the following survey statement.

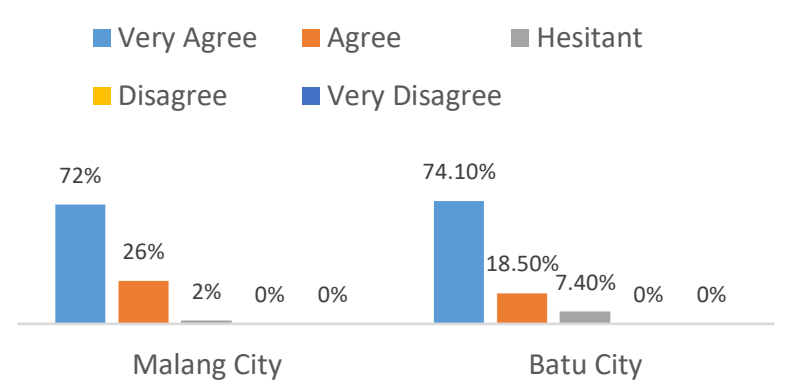

Fig. 1. Students' Perception on Pancasila as the most appropriate Ideology to Indonesia

Pancasila as the state's ideology still have substantial place to student. In addition, the students' awareness of the importance of Pancasila implementation in living within society is sufficiently high. This condition can be seen from the data below.

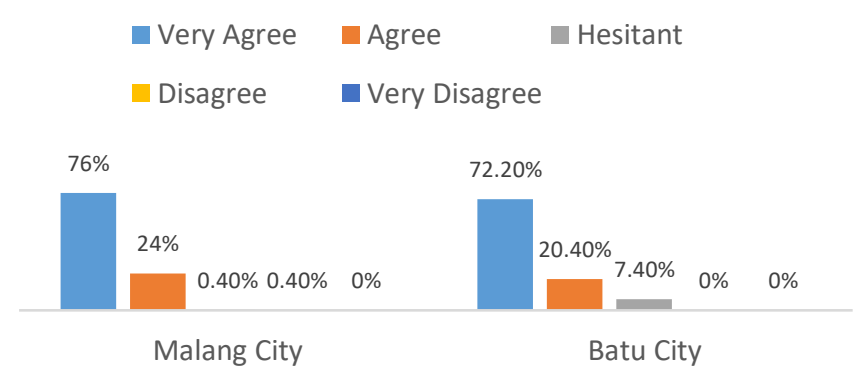

Fig 2. Students' Perception on the statement "every citizen obligatorily implement Pancasila

Students' perception on Pancasila seems to be not always in line with and consistent with religion and modernization. Although the percentage of very disagree and agree options is small, this data cannot be overridden. In addition, the hesitant option should be taken into account as well.

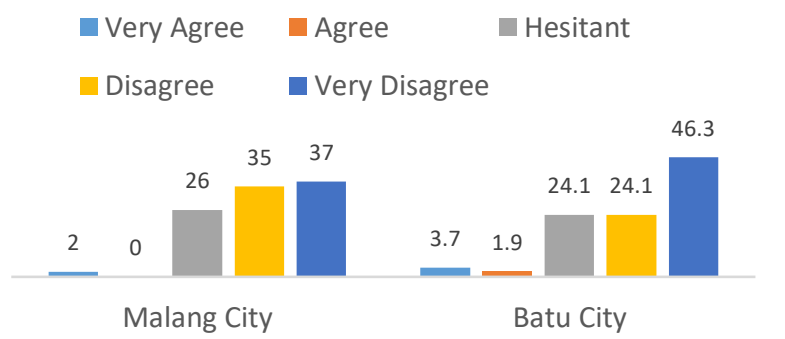

Fig 3. Students' Perception on the statement "Pancasila can be replaced with New More modern Ideology

Most students are not actually capable of deciding that Pancasila is indisputable. Their openness to modernization likely becomes the parameter to change the state's ideology. This reality also has same predisposition when Pancasila is 
is used based on.... (religion held on), because in... (his religion) mentions that the leader of world in the end of time is .... (the address for his religion's leader), rather than president".

This statement is uttered by a student who has ever contacted with radical group. He admitted that he often watched youtube about religion tenet and has ever joined whatsapp group teaches radicalism widely. He realized that the tenets delivered are in contradiction with the students' curiosity with their religion science study. Therefore, he utilized social media to learn much about religion.

Another student admitted that he has ever been included into whatsapp group themed student association. The group contains the promotion of religious studying activity by a religious leader indicated to adhere to radicalism thought because its tenet leads to intolerance. Meanwhile, another student states that he has contacted with radicalism, through telegram media. Information contained in the media even states clearly that they are the part of ISIS. Videos on the invitation to defend religion and to replace governance system are also appealed. Both students withdrew from those invitations by leaving the social media entrapping them. They still realize that the state's system is replaceable by the new system leading to their religion identity.

These three students are not active actors in radical group because they can withdraw from the social media entrapping them. Nevertheless, being free of the trap is not easy. Although social media becomes the sufficiently influential main channel, direct method remains to shadow them. The presence of people who always monitor them and invite them to rejoin their way always shadows them. They instead come from their relatives and colleagues. Such the trap can be relieved due because they can avoid the invitation to return continuously.

Although they can be liberated from radical group, in fact they have different perception on Pancasila. The student in the first case has an inherent tendency of distrusting in Pancasila. Meanwhile, the second and the third students still maintain Pancasila as the state's ideology.

\section{DISCUSSION}

Some previous studies mention that radicalism phenomenon can be observed from the perception on Pancasila. For example, the phenomenon of perception on Pancasila assuming that it is no longer relevant to apply to Indonesia. Radical groups can be identified generally through two phenomena: intolerance and attempt of replacing the state's ideology/system. It is this perception that the author uses to capture radicalism phenomenon among students.

"It does not matter to use Pancasila ideology today,

but in the future I agree more when another ideology 
Many previous studies have been conducted on similar case. For example, MAARIF Institute studied the Senior High School students in 50 Public Senior High Schools in 2011 and found that they tend to experience radicalism tenet internalization easily. Nevertheless, this research has difference. The author describes the surface phenomenon through survey. Furthermore, the author explores more indepth the students' experience with interaction with the radical group through social media, using interview technique. As a result, the author can describe the phenomenon in the following framework.

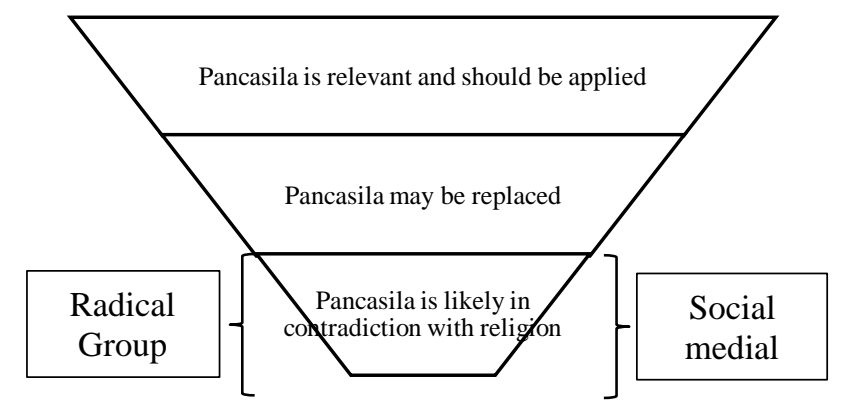

Fig 5. Result of Correlation between Perception and Reality of Radicalism Infiltration

This condition seems to be macro phenomenon difficult to identify. However, in this research, the author takes a stance to analyze it using mezzo-micro rather than macro perspectives. Closely observed, actually the contact between media and radical group makes an attack at individual level. This condition talks about the deviating socialization process inside individual and socialization agent. Nevertheless, this underground movement in reality can use technology and social media to promote its mission to spread radicalism. It means that information movement can be managed by radical groups disguisedly and vaguely. However, this condition will not be successful without the members of radical groups' intervention.

Radicalism can survive and be inculcated into an individual when social values and norms prevailing are no longer held on tightly by the individual. This condition of course does not occur suddenly, but there is a process aiming to erode those values and norms gradually. This process will be more effective when another one or a group is present to preserve it inside the individual. They serve to make the enacted values and norms powerless through intense approaches and interaction.

Nevertheless, individuals not interacting intensely with radical group and doing so only using social media can also be exposed to it. It should be confirmed by this research. This research can demonstrate only the condition of an individual having contact with media and radical group. These two powers in fact have not been able to encourage an individual to switch to radical group. The social power of main groups like school, house environment, and intercourse can be the power to expel those influences.

This condition shows the risk of modern community close to digital world. Interaction and effect of mass media becomes easier and removes spatial and temporal borders. At macro level, this condition according, to Ulrich Beck, becomes a part of risk society phenomenon. Social risk in modern society is related to the media now increasingly becoming mass consumption [8]. Media has been daily consumption to modern society, including Indonesian students. Therefore, this thinking risk becomes more difficult to study. Nonetheless, social disaster related to this radical thinking indeed becomes grey domain, the border of which cannot be determined certainly. The author mediates this dispute or debate by developing distinctive specific border, by confronting Pancasila ideology discourse and the state's system today with modernity and religion. Through the border, statistic data is obtained that has been elaborated and evidently can screen the indication of radicalism, despite low percentage. It is only a small portrait the author uses to describe how this study captures the radicalism phenomenon.

The role of media in certain case is not enough; the presence of group to monitor and to ensure that the targeted students keep in the radical tenet track is in fact needed. At this level, technological determinism concept becomes an aid to the author to explain the phenomenon [9]. In this discussion, the main finding highlighted shows that radicalism can be consumed by students through media. However, in fact media is not strong enough to ensure that the information transmitted can be consumed continuously. Therefore, the reinforcement through radical groups is needed. Direct interaction is needed to ensure that the students cannot get out of the bond (association) easily and maintain their social media consumption.

This research needs further development because of its many limitations. In the future the pattern to be used by a previous study conducted by Archetti can be an alternative reference. It is the research developed by means of exploring group's identity, perception on its existence, and perception on who have shared perception with their group. This method can be conducted longitudinally, so that more specific and obvious data can be obtained [10].

\section{REFERENCES}

[1] https://www.internetworldstats.com/top20.htm

[2] Buletin APJII Edisi 2019. Mengawali Integritas Era Digital 2019. Sumber:

https://apjii.or.id/downfile/file/BULETINAPJIIEDISI33Januari2019. pdf.

[3] Azca, Najib. 2013. Yang Muda, yang Radikal: Refleksi Sosiologis terhadap Fenomena Radikalisme Kaum Muda Muslim di Indonesia pasca orde Baru. Jurnal Ma`arif Vol. 8, p. 11 Juli 2013. 
[8] Beck, U. 1992. Risk Society, Towards a New Modernity. London: Sage.

[4] Munip, Abdul. 2012. Menangkal Radikalisme Agama di Sekolah Jurnal Pendidikan Islam Volume 1, nomor 2, Desember 2012.

[5] Abu Rokhmad. 2012. Radikalisme Islam dan Upaya Deradikalisasi Paham Radikal. Walisongo, Volume 20, Nomor 1, Mei.

[6] Undang-Undang No.10 Tahun 2004 tentang Pembentukan Peraturan Perundang-undangan.

[7] Bamualim, S. Chaider, Hilman Latief, Irfan Abubaar, Mohamad Nabil, Rita Pranawati, dan Wawan Setiawan. 2018. Kaum Muda Muslim Milenial: Konservatisme, Hibridasi Identitas, dan Tantangan Radikalisme. CRSC: Jakarta

[9] Gilles de Kerchove in BBC News (2014) "Islamic State crisis: '3,000 European jihadists join fight. available from: http://www.bbc.co.uk/news/world-middleeast-29372494.

[10] Cristina Archetti. 2015. Terrorism, Communication and New Media Explaining Radicalization in the Digital Age. Source: Perspectives on Terrorism, Vol. 9, No. 1 (February 2015), pp. 49-59. https://www.jstor.org/stable/26297326 